\title{
A systematic review of questionnaires used to measure the time spent on family care for frail older people
}

Sophie Cès, Johanna De Almeida Mello, Jean Macq, Thérèse Van Durme, Anja Declercq, Olivier Schmitz

\section{Introduction}

The commitment of the family carers to support frail older persons at home is an important issue for policymakers in the context of an ageing population. Being able to more accurately measure the time spent on family caring is therefore crucial for several reasons.

Caring has an impact on labour force participation (Bolin et al., 2008). Moreover, health care programmes may have an impact on the distribution of costs between the public budget and the private sphere (Weatherly et al., 2009, Drummond et al., 2005). Therefore, family care has to be integrated into economic evaluations, despite a lack of consensus on the best method to do this (Goodrich et al., 2012, Midy and Grignon, 2002, van den Berg et al., 2004). Measurement of the time spent on caring is an essential component used in various methods of evaluation of family care (van den Berg and Spauwen, 2006, Gerves et al., 2014, van den Berg et al., 2004, van den Berg and Ferrer, 2007). This indicator is also an interesting direct measure of the "objective burden" of carers.

However, there are problems with identifying the care activities that should be included to adequately measure the time spent on caring (van den Berg et al., 2004, Casey, 2011). Indeed, since family care is a partially "invisible" complex social process (Saillant, 1999, Membrado, 2005, Jansson et al., 2001) with multiple dimensions such as "practice", "knowledge", "presence” [...] (Saillant, 2000), or the accountability for the care recipient assumed by the family carers (Saillant and Gagnon, 2001), there is a considerable risk that a "reductionist" approach is adopted focusing only on the instrumental tasks (Membrado, 2005, Rigaux, 2009, Membrado, Lavoie, 2000). Hence, our first hypothesis is that the list of tasks mentioned in questionnaires used to measure time spent on family caring may not be exhaustive enough, i.e., important time-consuming tasks are omitted. Our second hypothesis is that explicit and well-defined choice of tasks is required since the frontier with 'normal' activities may sometimes be blurred, i.e., some activities listed in questionnaires may not be specific to caring. Hence, we aim to propose a comprehensive list of tasks that can be used to adequately measure the time spent on caring.

\section{Methods}

To evaluate the validity of the content of questionnaires, we categorized the domain of action of family carers into two types: activities of daily living defined as "frequent common activities, including selfcare, home maintenance and communication" (Tornquist and Sonn, 2014); and intangible activities, i.e., those difficult to observe. The distinction between activities and actions proposed by Tornquist is also useful to analyse the content of questionnaires (Tornquist and Sonn, 2014): "the activity consists of a 
group or a cluster or a sequence of actions, which are parts of components of the activity, and the activity is always something more than its action."

To test the comprehensiveness of the activities mentioned in the questionnaires measuring time spent on caring, we used a list of activities performed on a daily basis described in validated scales measuring the functional limitations in performing these activities: the Activities of Daily Living (ADLs), "activities oriented toward taking care of one's own body" (AOTA, 2014) and the Instrumental Activities of Daily Living (IADLs), "activities to support daily life within the home and community that often require more complex interactions than those used in ADLs" (AOTA, 2014). The rationale for comparing the content of the validated scales with the questionnaires is that family care is directly linked to functional disability.

For ADLs, we chose two scales because they have a good level of validity (Law and Letts, 1989) and have been widely used: the Katz Index of Independence in Activities of Daily Living (Katz et al., 1963, Robert et al., 2010) and the Barthel Index (Granger et al., 1979, DeLisa et al., 2005, Barthel, 1965) . These two scales assess the overall physical functioning of older adults using a list of daily activities. The Katz scale was elaborated according to the observation of reduced ability over time in the chronically illness and is used in different settings (Shelkey, 2012, Larson, 1991, McDowell, 2006). It is one of the few scales elaborated using theoretical conceptualisation of "primary biological functions" (McDowell, 2006). The Barthel index assesses more mobility items than does the Katz scale (mobility on level surfaces and stair use) and includes slightly more detail of personal care with grooming.

Finally, we assessed the completeness of the selected questionnaires by comparing the content with the Lawton IADL scale (Graf, 2007) measuring the level of disability for these activities. This scale has been tested on elderly people living at home and has been frequently used for this population (Vittengl et al., 2006, McDowell, 2006). We also considered the living arrangement of the carer (co-resident or not) with the care recipient. Indeed, for co-resident carers, household chores, home maintenance, outdoor work, finance management and shopping are public commodities (van den Berg et al., 2004), i.e., all cohabitants jointly benefit from these commodities, irrespective of whether or not they have disabilities. Therefore, the causal link between the loss of ability of the care recipient and these tasks is not obvious for co-resident carers. The solution proposed by van den Berg (Dumont et al., 2010, van den Berg and Spauwen, 2006) is to assess the increase in the time spent on doing these tasks as a result of a change in health status of frail older people. However, a longstanding caring relationship may hinder the assessment of the increase in workload. This solution may also be sex-biased, because these tasks are more routinely assumed by women than by men (Lee and Waite, 2008, Bianchi et al., 2000, Aassve et al., 2014). Men would declare more time spent on housework directly linked to the disability of their partners, whereas women may indicate a smaller increase in the time spent since they more often routinely performed these tasks before the occurrence of the functional limitations of their partner. According to this assumption, statistics about the carer's commitment and workload would not correctly 
reflect the reality for cohabitants. Indeed, the conclusion would pretend that men spent more time to help than women whereas the latter may actually have performed more IADLs and thus spent more time. At last, we also assert that housework is not necessary because of the presence of the care recipient as in fact carers would have to perform these tasks anyway after the care recipient has left the place. We, therefore, exclude these activities (including meal preparation) from time measurement for co-resident carers considering the weak correlation between the presence of the care recipient and the workload of these activities.

Intangible activities were identified in a qualitative study describing the role of family carers (Lavoie, 2000). Different types of activity were described: supervision, monitoring and psychological support. Firstly, supervision can be subdivided into the following categories: supervision of the care recipient and supervision of the formal care provided. We propose to restrict the supervision of the care recipient to the need for the presence of a family carer on a weekly-basis, i.e., the care recipient cannot stay alone to perform specific tasks or to prevent recurrent inappropriate behaviour, or the care recipient needs to be regularly advised on what to do at least on a weekly basis. Secondly, family carers may also perform some monitoring of the care recipient. This activity differs from supervision in that there is no systematic assistance on a regular basis. The aim of monitoring is to ensure a presence when there is a particular health risk because of acute health episodes. Finally, we consider psychological support as inherent to any affective relationship that cannot be univocally circumscribed (Rigaux, 2009). It should thus be excluded from the time measurement, except for cognitively impaired persons for whom the reciprocity of such support likely disappears as cognitive impairment worsens. In this case, psychological support is provided alongside other help as soon as there is contact between the carer and the care recipient. Therefore, we consider that the time spent on such support is already included by assessment of the duration of other forms of help and should thus be excluded from the time estimation.

Help with leisure activities or with maintaining social relationships is also difficult to delineate from "normal" activity in the setting of affective boundaries. We propose that the inclusion of such activity should be limited to the care recipients with significant loss of cognitive abilities as help with stimulating the frail older people can be considered part of the medical treatment in this case.

\section{Literature search and selection}

To identify the questionnaires used for measuring time spent on caring, we performed a systematic review of relevant studies. We searched the following databases for studies mentioning time spent on caring: MEDLINE (OVID), Embase (Embase.com), EconLit (EBSCO), PsycInfo (ProQuest), Sociological Abstract (ProQuest), Scopus and Cairn. Different terms and keywords were used to target family care: carers (Mesh term) or care, caring, carer, caregiver, caregiving and family or unpaid or informal. 
A total of 2944 articles were identified, to which 6 were added by the snowball method. Two researchers (Sophie Cès and Johanna de Almeida Mello) selected the papers in two steps: firstly, from the title and scanning of the abstract (471 articles selected) and secondly, by full-text reading (59 articles selected). Criteria for selection were: studies validating time-use instruments of family care or assessing the time spent on family care or mentioning a time estimation of family care for frail older persons (either exclusively or not). Studies on specific diseases were excluded in order to avoid questionnaires focusing on a specific type of impairment, with the exception of dementia because of the high degree of disability at the end-of-life stage (the "population" criteria in the flow chart). Indeed, questionnaires designed for carers of persons with particular diseases may exclude some activities since the types of impairment may be limited (e.g. only functional limitations). The review was limited to the questionnaires used to broadly assess informal care for frail older people since the ultimate goal is to propose a list of activities to consider regardless the cause of disability. Additionally, only studies in high income countries, i.e., Europe, USA, Canada, Asia, Australia, and studies for which the questionnaires were in English, Spanish, Dutch or French were selected because of the languages mastered by the two researchers.

All types of questionnaire were included (national or international surveys, validated time-use instruments, and ad-hoc questionnaires) except for those with only one question on the time measurement without any list of activities. 
Figure 1 Flow chart of the selection of articles

Figure 1 Flow chart of the selection of articles

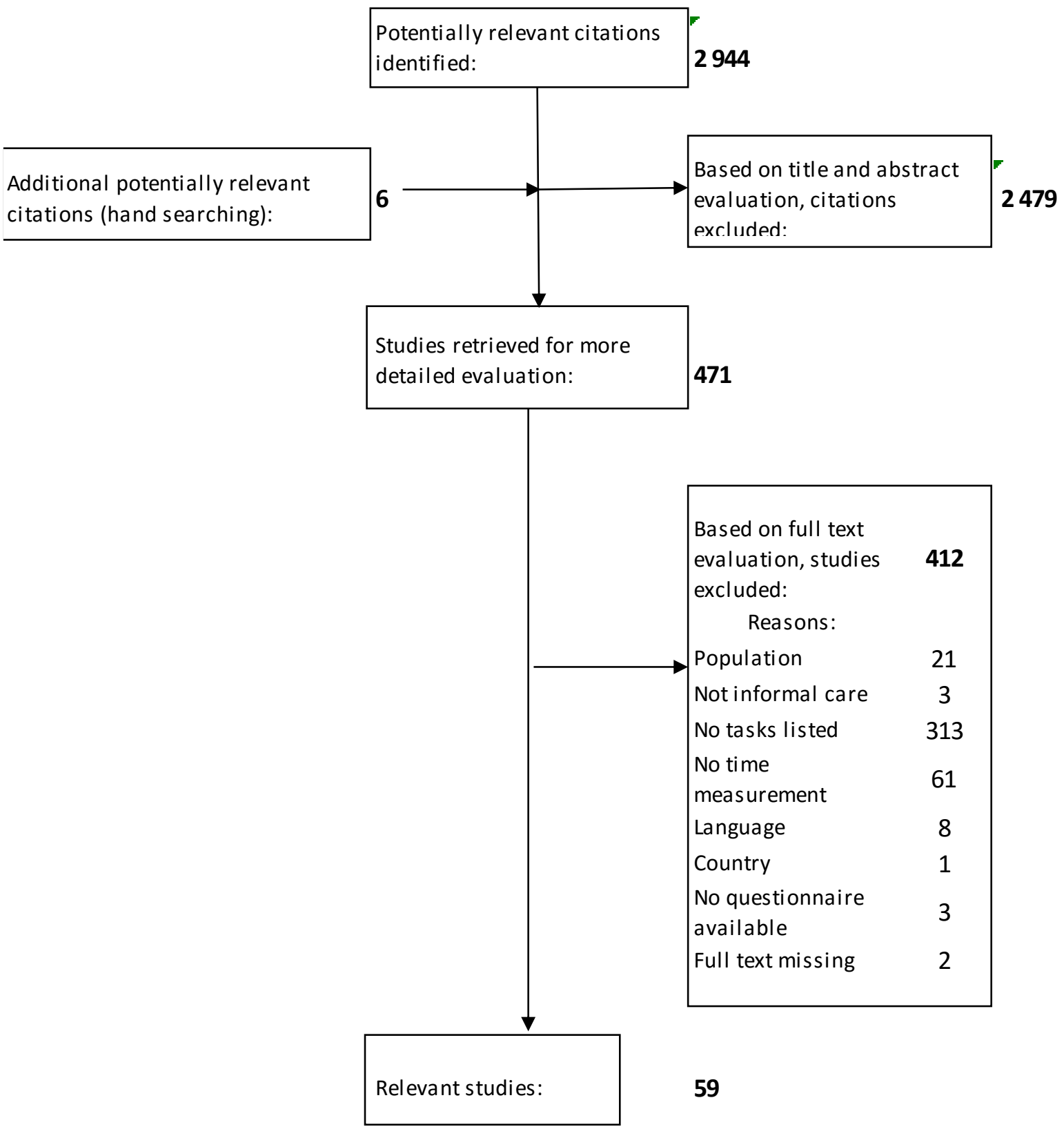

\section{Data analysis}

The activities mentioned in the selected questionnaires were analysed by two researchers using a software for qualitative data analysis (Nvivo version 10). This first synthesis of the activities listed in the questionnaires was subsequently validated by a second researcher. In a second stage, a critical review of the content of the questionnaires was performed.

\section{Results}

Nineteen questionnaires reported in 59 studies were selected for the review. We differentiated three types of questionnaire: instruments focusing on the time measurement of caring validated using 
psychometric properties; ad-hoc questionnaires elaborated for a specific study; and national or international surveys that may have had a broader focus than time measurement and had recurrent data collection.

Table 1 Overview of the validated instruments

\begin{tabular}{|c|c|c|c|}
\hline Name & $\begin{array}{c}\text { Target } \\
\text { population }\end{array}$ & $\begin{array}{l}\begin{array}{l}\text { References on the } \\
\text { validation of the } \\
\text { questionnaire }\end{array} \\
\end{array}$ & $\begin{array}{l}\text { References of studies using } \\
\text { time measurement }\end{array}$ \\
\hline $\begin{array}{l}\quad \text { Resource } \\
\text { Utilization in } \\
\text { Dementia } \\
\text { (RUD lite) }\end{array}$ & $\begin{array}{l}\text { Family carers of } \\
\text { people with dementia }\end{array}$ & $\begin{array}{l}\text { (Wimo et al., 2010, } \\
\text { Wimo and Nordberg, } \\
\text { 2007, Neubauer et al., } \\
\text { 2009a) }\end{array}$ & $\begin{array}{l}\text { (Bakker et al., 2013, Chong et } \\
\text { al., 2013, Ersek et al., 2010, } \\
\text { Gerves et al., 2014, Gustavsson et } \\
\text { al., 2011, Gustavsson et al., 2010, } \\
\text { Haro et al., 2014, Nordberg et al., } \\
\text { 2005, Wang et al., 2010, Wimo et } \\
\text { al., 2013, Jönsson et al., 2006, } \\
\text { Neubauer et al., 2008, Neubauer et } \\
\text { al., 2009c) }\end{array}$ \\
\hline $\begin{array}{l}\text { van den } \\
\text { Berg } 2006\end{array}$ & Family carers & $\begin{array}{l}\text { (Van Den Berg and } \\
\text { Spauwen, 2006) }\end{array}$ & $\begin{array}{l}\text { (Van Den Berg and Spauwen, } \\
2006)\end{array}$ \\
\hline $\begin{array}{l}\quad \text { Carer } \\
\text { Activity } \\
\text { Survey } \\
\text { (CAS) } 1997 \\
\end{array}$ & $\begin{array}{l}\text { Family carers of } \\
\text { individuals with } \\
\text { Alzheimer disease }\end{array}$ & $\begin{array}{l}\text { (Marin et al., 2000, } \\
\text { Davis et al., 1997) }\end{array}$ & $\begin{array}{l}\quad \text { (Jackson et al., 2013, } \\
\text { Schneider et al., 2002, Gage et al., } \\
\text { 2015) }\end{array}$ \\
\hline $\begin{array}{l}\quad \text { Carer } \\
\text { Activity } \\
\text { Time Survey } \\
\text { (CATS) } \\
\text { 1996 }\end{array}$ & $\begin{array}{l}\text { Family carers of } \\
\text { individuals with } \\
\text { Alzheimer disease }\end{array}$ & (Clipp et al., 1996) & (Shikiar et al., 2000) \\
\hline
\end{tabular}

Table 2 Overview of the ad-hoc questionnaires

\begin{tabular}{|c|c|c|c|}
\hline & Target population & Country & $\begin{array}{l}\text { References of studies } \\
\text { using time measurement }\end{array}$ \\
\hline $\begin{array}{l}\text { Dumont } \\
2010\end{array}$ & $\begin{array}{cc}\text { Family carers } & \text { of } \\
\text { palliative care patients }\end{array}$ & Canada & (Dumont et al., 2010) \\
\hline Harrow 2004 & $\begin{array}{l}\text { Family carers of } \\
\text { individuals with Alzheimer } \\
\text { disease }\end{array}$ & $\begin{array}{l}\text { United } \\
\text { States }\end{array}$ & (Harrow et al., 2004) \\
\hline $\begin{array}{l}\text { Jakobsen } \\
2011\end{array}$ & $\begin{array}{l}\text { Family carers of people } \\
\text { with dementia }\end{array}$ & Denmark & (Jakobsen et al., 2011) \\
\hline Hassink 2011 & Family carers & Netherlands & $\begin{array}{l}\text { (Hassink and Van Den } \\
\text { Berg, 2011) }\end{array}$ \\
\hline
\end{tabular}


Table 3 Overview of the national or international surveys

\begin{tabular}{|c|c|c|c|c|}
\hline & Target population & Countries & $\begin{array}{l}\text { Main goal of } \\
\text { the } \\
\text { questionnaire }\end{array}$ & 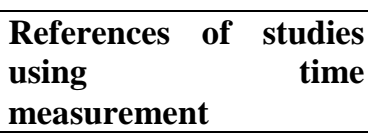 \\
\hline $\begin{array}{l}\text { Handicap- } \\
\text { Santé } 2008 \text { questionnaires for } \\
\text { resident and non-resident } \\
\text { carers }\end{array}$ & $\begin{array}{l}\text { Family carers of } \\
\text { disabled persons or } \\
\text { dependent older } \\
\text { people }\end{array}$ & France & Family care & $\begin{array}{l}\text { (Davin and Paraponaris, } \\
\text { 2012, Paraponaris and } \\
\text { Davin, 2015, Soullier, } \\
\text { 2011) }\end{array}$ \\
\hline $\begin{array}{l}\text { National Carers Questionnaire } \\
1996\end{array}$ & $\begin{array}{l}\text { Family carers of } \\
\text { adults over the age } \\
\text { of } 50 \text { years }\end{array}$ & $\begin{array}{l}\text { United } \\
\text { States }\end{array}$ & Family care & $\begin{array}{l}\text { (Ory, Hoffman, Lee, } \\
\text { Tennstedt, \& Schulz, } \\
\text { 1999) }\end{array}$ \\
\hline $\begin{array}{l}\text { National Carers Questionnaire } \\
2009\end{array}$ & $\begin{array}{l}\text { Family carers of } \\
\text { adults over the age } \\
\text { of } 18 \text { years }\end{array}$ & $\begin{array}{l}\text { United } \\
\text { States }\end{array}$ & Family care & (Barrett, 2009) \\
\hline $\begin{array}{l}\text { Disability, Independence and } \\
\text { Dependency Situations Survey } \\
\text { (EDAD -2008) }\end{array}$ & $\begin{array}{l}\text { Family carers of } \\
\text { disabled persons }\end{array}$ & Spain & Multi-purpose & $\begin{array}{l}\text { (Marcenaro-Gutierrez et } \\
\text { al., 2012, Oliva et al., } \\
2011 \text {, Oliva-Moreno et } \\
\text { al., 2013, Pen- } \\
\text { Longobardo and Oliva- } \\
\text { Moreno, 2014b, Peña- } \\
\text { Longobardo and Oliva- } \\
\text { Moreno, 2014a, Jimenez- } \\
\text { Martin and Prieto, 2012) }\end{array}$ \\
\hline $\begin{array}{l}\text { Common Assessment Tool } \\
\text { (CAT) } 2004\end{array}$ & $\begin{array}{l}\text { Family carers of } \\
\text { persons aged } 65 \text { or } \\
\text { more }\end{array}$ & $\begin{array}{l}\text { Germany } \\
\text { Greece, } \\
\text { Italy, } \\
\text { Poland, } \\
\text { Sweden UK }\end{array}$ & Family care & $\begin{array}{l}\text { (Balducci et al., 2008, } \\
\text { Perrig-Chiello and } \\
\text { Hutchison, 2010, Alwin } \\
\text { et al., 2010) }\end{array}$ \\
\hline $\begin{array}{l}\text { Survey of Health, Ageing and } \\
\text { Retirement in Europe } \\
\text { (SHARE) } \\
\text { Waves } 1(2004 / 05)\end{array}$ & Aged 50 or over & $\begin{array}{l}\text { European } \\
\text { countries } \\
\text { and Israel }\end{array}$ & Multi-purpose & $\begin{array}{l}\text { (Albertini et al., 2007, } \\
\text { Bolin et al., 2008a, Bolin } \\
\text { et al., 2008c, Bonsang, } \\
\text { 2009) }\end{array}$ \\
\hline $\begin{array}{l}\text { Survey of Health, Ageing and } \\
\text { Retirement in Europe } \\
\text { (SHARE) } \\
\text { Waves-2 (2006/07) }\end{array}$ & Aged 50 or over & $\begin{array}{l}\text { European } \\
\text { countries } \\
\text { and Israel }\end{array}$ & Multi-purpose & $\begin{array}{l}\text { (Gannon and Davin, } \\
\text { 2010, Alessie et al., 2014, } \\
\text { Balia and Brau, 2014) }\end{array}$ \\
\hline $\begin{array}{l}\text { General Social Survey } 2007 \\
\text { (GSS) }\end{array}$ & $\begin{array}{l}\text { Aged } 45 \text { and over } \\
\text { living in private } \\
\text { households }\end{array}$ & Canada & Multi-purpose & (Jacobs et al., 2013) \\
\hline $\begin{array}{l}\text { General Social Survey } 1996 \\
\text { (GSS) }\end{array}$ & $\begin{array}{l}\text { All persons } 15 \\
\text { years of age and } \\
\text { older }\end{array}$ & Canada & Multi-purpose & $\begin{array}{l}\text { (Latif, 2006, Lapierre and } \\
\text { Keating, 2013) }\end{array}$ \\
\hline $\begin{array}{l}\text { National Long-Term Care } \\
\text { Survey (NLTCS) } 1999\end{array}$ & $\begin{array}{l}\text { All persons } 65 \text { and } \\
\text { older }\end{array}$ & $\begin{array}{l}\text { United } \\
\text { States }\end{array}$ & Multi-purpose & $\begin{array}{l}\text { (Wolff et al., 2007, } \\
\text { Moore et al., 2001, Hong, } \\
\text { 2006, Taylor et al., 2008) }\end{array}$ \\
\hline $\begin{array}{l}\text { National Long-Term Care } \\
\text { Survey (NLTCS) } 2004\end{array}$ & $\begin{array}{l}\text { All persons } 65 \text { and } \\
\text { older }\end{array}$ & $\begin{array}{l}\text { United } \\
\text { States }\end{array}$ & Multi-purpose & $\begin{array}{l}\text { (Hong, 2010, Casado et } \\
\text { al., 2011) }\end{array}$ \\
\hline
\end{tabular}

\section{Activities of Daily Living}

For the ADL, the measurement of the time spent on caring is straightforward, because tasks are observable and less likely to be influenced by cultural context than Instrumental Activities of Daily Living. However, two shortcomings in time measurement were identified. Firstly, most of the 
questionnaires were broad and general without describing the actions related to the activities. All questionnaires mentioned personal care but most of them did not provide the full list of actions related to this activity: three questionnaires did not list any action; two questionnaires mentioned only bathing; six questionnaires listed bathing and showering only; five questionnaires listed two other actions; one listed three actions; and only one mentioned six different actions. Secondly, even general tasks were sometimes omitted. Mobility inside the house and dressing were the most frequently cited activities (17/19). Sixteen questionnaires included help with eating, thirteen with using the toilet and nine with bed chair transferring. Finally, help when a person suffers from incontinence was the most rarely mentioned activity (4/19). Overall, only three questionnaires mentioned the six activities considered in the Katz scale and the Barthel index: personal care (bathing, grooming), dressing, eating, mobility inside the house (stair use, mobility on level surfaces, transfers), toilet use and incontinence (bowel, bladder).

\section{Instrumental Activities of Daily Living}

Similarly to the ADL, there are limitations in the completeness of questionnaires for IADL support. Only three questionnaires mentioned the seven types of activity considered in the Lawton IADL scale. The most frequent tasks listed were help with shopping, finances, housekeeping and transportation (16/19), laundry (10/19) and food preparation (13/19). However, some questionnaires provided no detail regarding the actions and simply mentioned "housework", "house chores". Medication taking was cited in 12 questionnaires and telephone use in only four questionnaires.

\section{The particular status of IADLs for resident family carers}

In the 19 questionnaires reviewed, three questionnaires had different questions based on the living arrangements of the family carer (co-resident or not). However, the Handicap-Santé 2008 survey is the only questionnaire that really distinguished between IADL tasks based on the living arrangements of the family carer. The version for extra-resident family carers included help with meal preparation, laundry, cleaning the home, home maintenance, dishwashing, financial management, shopping and outdoor work, whereas the version for co-resident family carers did not include these tasks if carers were already used to do it before the occurrence of disability . The SHARE survey also mentioned the living arrangements of the family carer (waves 1 and 2), but the estimation of time spent on caring was entirely limited to the extra-resident family carers.

\section{Other activities cited but not listed in the Lawton scale}

The following tasks not included in the Lawton scale were also mentioned in the selected questionnaires:

- Help with health care treatment (e.g. "physiotherapy, massages, medical care such as dialysis, injections, bandages, heart monitor, blood sugar tests") was cited in six questionnaires. This type of task is worth mentioning since the amount of time needed may be considerable in persons with severe illness, multi-morbidity or end-stage disease. Technical tasks may also require considerable time to be spent acquiring the necessary skills, especially in the case of medical care, 
such as dialysis, where the family carer is also supposed to act competently in cases of problems with the treatment or with a monitoring device.

- Mobility outside the house such as help with walking or with mobility with aids (in 5 questionnaires) is a task which can be easily assessed.

- The inclusion of "Finding the person if they get lost" (in 1 questionnaire) and "find things that are lost" (in 1 questionnaire) draws attention to potentially important tasks in looking after a care recipient with cognitive impairment.

- Making appointments and arrangements for the provision of care was included in five questionnaires and should be, because organization of formal services delivery can be timeconsuming at specific moments, such as crisis situations or acute episodes of ill health (Saillant and Dandurand, 2002).

- The time taken to get to the care recipient's home is seldom included in questionnaires (3 questionnaires over 19). This type of activity is not a direct form of help, but is a prerequisite for being able to provide help. Moreover, this activity is sometimes an important factor influencing the involvement of family carers (Joseph and Hallman, 1998).

- House adaptations (in one questionnaire), home maintenance and outdoor work (in seven questionnaires) are not activities that are regularly performed. Moreover, some of them may not be an absolute necessity to supporting the care recipient (e.g., decorating).

- Visiting family or friends and leisure participation are mentioned in five questionnaires without any condition on the care recipient's profile.

\section{Intangible activities}

Supervision was not included in the majority of the questionnaires reviewed (13/19). Three questionnaires mentioned supervision without giving any further detail, and three questionnaires mentioned precise examples of supervision: communication with the care recipient to remind them how and when to do things or to answer repeated questions, or preventing the person from getting lost (the Carer Activity Survey 1997). Night disturbances were mentioned in the questionnaire by Jakobsen (Jakobsen et al., 2011) and night supervision in the Handicap-Santé 2008 survey (both non-resident and resident questionnaires). Both are interesting to mention because help during the night may be less associated with specific tasks.

Two questionnaires included monitoring of the condition of the care recipient (e.g., "visiting or calling to make sure...").

Psychological support (emotional, psychological, social support, presence) was mentioned in four questionnaires. 
Table 4 Overview of the activities mentioned in the 19 questionnaire reviewed

\begin{tabular}{|c|c|c|}
\hline & & $\begin{array}{c}\text { Number of } \\
\text { questionnaire with } \\
\text { mention of the activity }\end{array}$ \\
\hline \multirow{6}{*}{$\begin{array}{l}\text { ADLs in the Katz } \\
\text { scale and the Barthel } \\
\text { Index }\end{array}$} & Personal hygiene care & 19 \\
\hline & Dressing & 17 \\
\hline & Feeding & 16 \\
\hline & Mobility & 17 \\
\hline & Toilet use & 13 \\
\hline & Continence & 4 \\
\hline \multirow{8}{*}{$\begin{array}{l}\text { IADLs in the Lawton } \\
\text { scale }\end{array}$} & Meal preparation & 13 \\
\hline & Housekeeping & 16 \\
\hline & Laundry & 10 \\
\hline & Finance management & 16 \\
\hline & Medication & 12 \\
\hline & Phone use & 4 \\
\hline & Shopping & 16 \\
\hline & Transportation & 16 \\
\hline \multirow{7}{*}{$\begin{array}{l}\text { Other activities not } \\
\text { mentioned in the } \\
\text { Lawton scale }\end{array}$} & Participation to health treatment & 6 \\
\hline & Finding the care recipient when lost & 1 \\
\hline & Finding things lost & 1 \\
\hline & Organization of formal care & 5 \\
\hline & $\begin{array}{l}\text { Mobility outside the house (except } \\
\text { transportation) }\end{array}$ & 5 \\
\hline & Time to get to the care recipient's dwelling & 3 \\
\hline & Visiting family or friends and leisure participation & 5 \\
\hline \multirow{4}{*}{ Intangible activities } & Supervision of formal care & 0 \\
\hline & Supervision of the care recipient & 6 \\
\hline & Monitoring of the care recipient & 2 \\
\hline & Psychological support & 4 \\
\hline
\end{tabular}

\section{Synthesis}

The comparison of the content of questionnaires with the scales measuring functional limitations and with the intangible tasks described in the qualitative study shows important risks of misestimating the time spent on family caring. The majority of the questionnaires reviewed risk underestimating the time, because important time-consuming tasks are often left out, such as the management of incontinence or supervision. We also found considerable heterogeneity in the list of activities mentioned in the questionnaires and many of them did not provide enough details about actions regarding the activities. Moreover, the potential help provided to care recipients suffering from cognitive impairment is not often addressed (e.g., finding a person who is lost, lost objects...). There are also different sources of potential 
overestimation because of the inclusion of activities that are anyway often performed in the absence of a caring function (e.g., psychological support or visiting friends). Finally, there is no mention of the need for supervision in the questionnaires with a clear link to the degree of impairment of the care recipient. This omission may yield to an overestimation of the time spent on supervision because family carers may subjectively evaluate whether they provide such help or not.

From the content of the questionnaires and the two other data sources (validated scales and qualitative study), we developed a list of activities to consider in assessment of time spent on family caring. An important difficulty to consider is the risk of overlap between different moments in time. The first type of overlap is confusion in the time estimation: e.g., the time spent on helping with dressing can be counted several times, e.g., when helping with bathing or with toilet use. Therefore, each activity should be delineated as much as possible in terms of moments during the day. For instance, time spent in the bathroom is easily assessed, whereas moments of dressing are less identifiable because there are several occasions for dressing (in the morning, to go out, to get into bed...). Hence, to ease the time measurement, each activity for which the moment during the day is well circumscribed and identifiable should be assessed first. Other complementary activities can then be assessed outside the specific moments already evaluated: e.g., once the evaluation of time spent helping with personal hygiene care has already been performed, a complementary question is needed to assess the other moments used to help with dressing. This provides a kind of funnel structure for measuring time.

For intangible activities, the risk of overlap is real because family carers can perform these tasks at the same time as others. To avoid counting time twice, supervision and monitoring should thus be measured when no other help with ADLs or IADLs is provided (Wimo et al., 2000, Gerves et al., 2014). And monitoring should also be measured when no supervision is already provided.

Finally, it is also important to distinguish different levels of involvement in the personal intimacy of the care recipient when defining personal hygiene care. This differentiation is particularly useful to analyse specific behaviours according to the sex and family relationship of the family carer (e.g., differences between spouses and children). Therefore, we distinguished three types of activities with an increasing level of involvement in personal intimacy: grooming, bathing or showering, and urine and stool elimination, the latter demanding the highest level of intimate involvement.

Table 5 Activities of Daily Living to consider in the time measurement

\begin{tabular}{|c|c|c|c|}
\hline \multirow{5}{*}{\begin{tabular}{l}
\multicolumn{1}{c}{ Personal } \\
hygiene care \\
\multicolumn{2}{c}{ (including } \\
help with \\
mobility)
\end{tabular}} & $\begin{array}{l}\text { Grooming } \\
\text { (particular parts of the } \\
\text { body) }\end{array}$ & \multicolumn{2}{|c|}{$\begin{array}{l}\text { Shaving, combing, brushing teeth, washing hands, face and } \\
\text { nail care }\end{array}$} \\
\hline & $\begin{array}{l}\text { Bathing } \\
\text { showering }\end{array}$ & \multicolumn{2}{|c|}{$\begin{array}{l}\text { Getting in/out of the bathtub or the shower, washing, rinsing, } \\
\text { drying off and dressing/undressing }\end{array}$} \\
\hline & \multirow{3}{*}{$\begin{array}{l}\text { Urine and stool } \\
\text { elimination }\end{array}$} & Toilet use & \multirow{3}{*}{$\begin{array}{l}\text { undressing/dressing, mobility, } \\
\text { cleaning after elimination, washing hands, } \\
\text { or putting on and taking off diapers }\end{array}$} \\
\hline & & Bed pan use & \\
\hline & & $\begin{array}{l}\text { Management of } \\
\text { incontinence }\end{array}$ & \\
\hline
\end{tabular}




\begin{tabular}{|c|c|c|}
\hline \multirow{2}{*}{ Other } & Dressing/undressing & $\begin{array}{c}\text { Getting dressed or undressed (upper and lower trunk), } \\
\text { including tying shoelaces or fastening buttons for any other } \\
\text { occasions than personal hygiene care }\end{array}$ \\
\cline { 2 - 4 } & $\begin{array}{c}\text { Help with mobility to get to the room/ to sit down, cutting, } \\
\text { spreading food, serving and/or helping with getting food or liquid } \\
\text { into the person's mouth }\end{array}$ \\
\hline $\begin{array}{c}\text { Mouse } \\
\text { hobility inside the }\end{array}$ & $\begin{array}{c}\text { At any other moment not previously mentioned, transfers in } \\
\text { bed, bed to chair transferring (or between chairs), walking around } \\
\text { in the house on the same level, moving from one floor to another } \\
\text { (with or without any specific aid equipment) }\end{array}$ \\
\hline
\end{tabular}

Table 6 Instrumental Activities of Daily Living to consider in the time measurement

\begin{tabular}{|c|c|c|}
\hline \multirow{4}{*}{$\begin{array}{l}\text { For extra-resident } \\
\text { carers only }\end{array}$} & $\begin{array}{l}\text { Meal preparation: } \\
\text { food for the care recipient } \\
\text { only }\end{array}$ & $\begin{array}{l}\text { Washing, peeling, cutting vegetables or fruit, using } \\
\text { and washing equipment, heating food or liquids and } \\
\text { laying table }\end{array}$ \\
\hline & $\begin{array}{l}\text { Shopping: groceries } \\
\text { for the care recipient only }\end{array}$ & Getting to shops, paying and bringing home \\
\hline & Finances & Bills, banking, legal matters, insurance,... \\
\hline & $\begin{array}{l}\text { Housekeeping: only } \\
\text { tasks performed on a } \\
\text { regular basis }\end{array}$ & $\begin{array}{l}\text { Dishwashing, dusting, cleaning up, washing floors, } \\
\text { windows, straightening up, putting things away or finding } \\
\text { things that are lost. }\end{array}$ \\
\hline \multirow{6}{*}{$\begin{array}{l}\text { For all family } \\
\text { carers }\end{array}$} & $\begin{array}{l}\text { Laundry of the } \\
\text { clothes/sheets of the care } \\
\text { recipient }\end{array}$ & Washing clothes/sheets, ironing, tidying up, sewing \\
\hline & $\begin{array}{l}\text { Transportation to } \\
\text { and/or participation at } \\
\text { medical or administrative } \\
\text { appointments }\end{array}$ & $\begin{array}{l}\text { Use of any transportation means or help with mobility } \\
\text { outside home (with walking or with aids) for medical or } \\
\text { administrative purposes (excluding leisure) }\end{array}$ \\
\hline & $\begin{array}{l}\text { Transportation to visit } \\
\text { friends or family or } \\
\text { participation in leisure } \\
\text { activity }\end{array}$ & $\begin{array}{l}\text { Use of any transportation means or help with mobility } \\
\text { outside home, only for care recipients with significant } \\
\text { cognitive impairment }\end{array}$ \\
\hline & \multirow[b]{2}{*}{$\begin{array}{l}\text { Health treatment at } \\
\text { home }\end{array}$} & Medication: pills, injections, infusions, \\
\hline & & $\begin{array}{l}\text { Other participation for treatments: wound care, use of } \\
\text { health technical device, physiotherapy or massages, } \\
\text { emotional, behavioural therapies... }\end{array}$ \\
\hline & $\begin{array}{l}\text { Organisation } \\
\text { formal support }\end{array}$ & $\begin{array}{l}\text { Making appointments, arrangements for the provision } \\
\text { of care or social/health services (e.g., participation at } \\
\text { coordination meetings) }\end{array}$ \\
\hline
\end{tabular}

Table 7 Intangible activities to consider in the time measurement

\begin{tabular}{|l|l|}
\hline Supervision of formal care & $\begin{array}{l}\text { When there is a particular need for the presence of the family carer, such } \\
\text { as professional turnover or the care plan being changed, (communication } \\
\text { needed, control of the quality of care, respect for the integrity of the care } \\
\text { recipient...) }\end{array}$ \\
\hline
\end{tabular}




\section{Supervision of the care recipient}

(only moments when no other help with activities previously mentioned is provided)
In case of a potential risks of harming him- or herself and/or others or preventing the person from having inappropriate behaviour: communication with the care recipient to remind about/explain things to do, night supervision, at least on a weekly basis

\section{Monitoring of the care recipient}

(only moments when no other help with activities previously mentioned is provided)

Presence of family carer required in case of a high risk of health status worsening

Finally, two other important tasks, which are not direct help activities, also need to be considered in the time measurement. Indeed, they involve the family carers, are potentially time-consuming and are directly related to the support of frail older people: commuting to the care recipient's dwelling and finding the care recipient when he/she gets lost.

\section{Conclusion}

Building a quantitative indicator to measure a complex social phenomenon requires clarification of the approach in order to be able to interpret the results, particularly regarding activities excluded from the measurement and the risks of bias. We critically analysed the content of several questionnaires using an analytical framework based on a combination of intangible activities, ADLs, and IADLs. Comparing the questionnaires with the activities listed in validated scales and a qualitative study enabled identification of important drawbacks of the questionnaires. From the synthesis of the three data sources, we were able to build a comprehensive list of contextualized activities, which is not only useful for measuring the time spent on caring, but also provides the possibility of an in-depth analysis of family care supply. However, determining which activities to measure represents a compromise between the specificity of the measurement, which requires ruling out activities not directly linked to the disability of the care recipients, and a definition of family care that is too narrow, potentially excluding relevant and time-consuming activities. Indeed, the frontier between 'normal' and 'family' care is sometimes tenuous and dependent on the profile of the care recipient.

The list proposed constitutes a first step in the design of a questionnaire enabling the time measurement of family care of frail older people. A qualitative study among carers would be necessary both to validate the list of activities on comprehensiveness and understanding and to identify potential practical issues. Finally, to better grasp the importance of the family carer's commitment, we advocate examination of other important dimensions that cannot be included in the time measurement, such as for example, being constantly on call. Hence, further research using qualitative methods would be useful to develop 
qualitative questions that can more comprehensively reveal the different degrees of accountability borne by family carers (Membrado, 2005, Saillant and Gagnon, 2001). 


\section{Reference list}

Aassve, A. Fuochi, G. \& Mencarini, L. (2014) 'Desperate Housework: Relative Resources, Time Availability, Economic Dependency, and Gender Ideology Across Europe', Journal of Family Issues, 35(8): 1000-1022.

Albertini, M. Kohli, M. \& Vogel, C. (2007) 'Intergenerational transfers of time and money in European families: Common patterns - Different regimes?', Journal of European Social Policy, 17(4): 319334.

Alessie, R. Angelini, V. \& Pasini, G. (2014) 'Is It True Love? Altruism versus Exchange in Time and Money Transfers', De Economist, 162(2): 193-213.

Alwin, J. Oberg, B. \& Krevers, B. (2010) 'Support/services among family caregivers of persons with dementia--perceived importance and services received', International journal of geriatric psychiatry, 25(3): 240-8.

AOTA (2014) 'Occupational Therapy Practice Framework: Domain and Process 3rd Edition', The American Journal of Occupational Therapy, 68.

Bakker, C. de Vugt, M. E. van Vliet, D. Verhey, F. R. J. Pijnenburg, Y. A. Vernooij-Dassen, M. J. F. J. \& Koopmans, R. T. C. M. (2013) 'The use of formal and informal care in early onset dementia: results from the NeedYD study', American Journal of Geriatric Psychiatry, 21(1): 37-45.

Balducci, C. Mnich, E. McKee, K. J. Lamura, G. Beckmann, A. Krevers, B. Wojszel, Z. B. Nolan, M. Prouskas, C. Bien, B. \& Oberg, B. (2008) 'Negative Impact and Positive Value in Caregiving: Validation of the COPE Index in a Six-Country Sample of Carers', The Gerontologist, 48(3): 276286.

Balia, S. \& Brau, R. (2014) 'A Country for Old Men? Long-Term Home Care Utilization in Europe', Health Economics, 23(10): 1185-1212.

Barrett, L. L. (2009) Caregiving in the US. National Alliance for Caregiving in collaboration with

AARP.

Barthel, D. (1965) 'Functional evaluation: the barthel index, Maryland State', Med J, 1416-65.

Bianchi, S. M. Milkie, M. A. Sayer, L. C. \& Robinson, J. P. (2000) 'Is Anyone Doing the Housework ? Trends in the Gender Division of Household labor', Social forces, 79(1): 191-228.

Bolin, K. Lindgren, B. \& Lundborg, P. (2008a) 'Informal and formal care among single-living elderly in Europe', Health Economics, 17(3): 393-409.

Bolin, K. Lindgren, B. \& Lundborg, P. (2008b) 'Your Next of Kin or Your Own Career? Caring and Working among the 50+ of Europe', Journal of Health Economics, 27(3): 718-738.

Bolin, K. Lindgren, B. \& Lundborg, P. (2008c) 'Your next of kin or your own career? Caring and working among the 50+ of Europe', Journal of Health Economics, 27(3): 718-38.

Bonsang, E. (2009) 'Does informal care from children to their elderly parents substitute for formal care in Europe?', Journal Of Health Economics, 28(1): 143-154.

Casado, B. L. van Vulpen, K. S. \& Davis, S. L. (2011) 'Unmet needs for home and community-based services among frail older Americans and their caregivers', Journal Of Aging And Health, 23(3): 529-553.

Casey, B. ( 2011) The Value and Costs of Informal care. Institute for Employment Research University of Warwick: Commission on Funding of Care and Support. 
Chong, M. S. Tan, W. S. Chan, M. Lim, W. S. Ali, N. Ang, Y. Y. \& Chua, K. C. (2013) 'Cost of informal care for community-dwelling mild-moderate dementia patients in a developed Southeast Asian country', International Psychogeriatrics / IPA, 25(9): 1475-1483.

Clipp, E. C. Moore, M. J. \& George, L. K. (1996) 'The content and properties of the Caregiver Activities Time Survey (CATS): An outcome measure for use in clinical trial research on Alzheimer's disease', American Journal of Alzheimer's Disease, 11(6): 3-9.

Davin, B. \& Paraponaris, A. (2012) 'Vieillissement de la population et dépendance Un coût social autant que médical', Institut de Recherche en Santé Publique, Questions de santé publique, 19(201212).

Davis, K. L. Marin, D. B. Kane, R. Patrick, D. Peskind, E. R. Raskind, M. A. \& Puder, K. L. (1997) 'The Caregiver Activity Survey (CAS): development and validation of a new measure for caregivers of persons with Alzheimer's disease', International Journal Of Geriatric Psychiatry, 12(10): 978988.

DeLisa, J. A. Gans, B. M. \& Walsh, N. E. (2005) Physical medicine and rehabilitation: principles and practice, Philadelphia: Lippincott Williams \& Wilkins.

Drummond, M. F. Sculpher, M. J. Torrance, G. W. O'Brien, B. J. \& Stoddart , G. L. (2005) Methods for the Economic Evaluation of Health Care Programmes, Oxford: Oxford University Press.

Dumont, S. Jacobs, P. Turcotte, V. Anderson, D. \& Harel, F. (2010) 'Measurement challenges of informal caregiving: a novel measurement method applied to a cohort of palliative care patients', Social Science \& Medicine (1982), 71(10): 1890-5.

Ersek, K. Kovacs, T. Wimo, A. Karpati, K. Brodszky, V. Pentek, M. Jonsson, L. Gustavsson, A. McDaid, D. Kenigsberg, P. A. Valtonen, H. \& Gulacsi, L. (2010) 'Costs of dementia in Hungary', Journal of Nutrition, Health and Aging, 14(8): 633-639.

Gage, H. Cheynel, J. Williams, P. Mitchell, K. Stinton, C. Katz, J. Holland, C. \& Sheehan, B. (2015) 'Service utilisation and family support of people with dementia: A cohort study in England', International Journal of Geriatric Psychiatry, 30(2): 166-177.

Gannon, B. \& Davin, B. (2010) 'Use of formal and informal care services among older people in Ireland and France', European Journal Health Economics, 11(5): 499-511.

Gerves, C. Chauvin, P. \& Bellanger, M. M. (2014) 'Evaluation of full costs of care for patients with Alzheimer's disease in France: The predominant role of informal care', Health Policy, 116(1): 114-122.

Goodrich, K. Kaambwa, B. \& Al-Janabi, H. (2012) 'The inclusion of informal care in applied economic evaluation: a review', Value Health, 15(6): 975-81.

Graf, C. (2007) The Lawton Instrumental Activities of Daily Living (IADL) Scale, Best Practices in Nursing Care to Older Adults The Hartford Institute for Geriatric Nursing.

Granger, C. V. Albrecht, G. L. \& Hamilton, B. B. (1979) 'Outcome of comprehensive medical rehabilitation: measurement by PULSES profile and the Barthel Index', Archives Of Physical Medicine And Rehabilitation, 60(4): 145-154.

Gustavsson, A. Cattelin, F. \& Jonsson, L. (2011) 'Costs of care in a mild-to-moderate Alzheimer clinical trial sample: Key resources and their determinants', Alzheimer's and Dementia, 7(4): 466-473.

Gustavsson, A. Jonsson, L. Rapp, T. Reynish, E. Ousset, P. J. Andrieu, S. Cantet, C. Winblad, B. Vellas, B. \& Wimo, A. (2010) 'Differences in resource use and costs of dementia care between European countries: baseline data from the ICTUS study', Journal of Nutrition Health and Aging, 14(8): 648-654. 
Haro, J. M. Kahle-Wrobleski, K. Bruno, G. Belger, M. DellnullAgnello, G. Dodel, R. Jones, R. W. Reed, C. C. Vellas, B. Wimo, A. \& Argimon, J. M. (2014) 'Analysis of burden in caregivers of people with Alzheimernulls disease using self-report and supervision hours', Journal of Nutrition, Health and Aging, 18(7): 677-684.

Harrow, B. S. Mahoney, D. F. Mendelsohn, A. B. Ory, M. G. Coon, D. W. Belle, S. H. \& Nichols, L. O. (2004) 'Variation in cost of informal caregiving and formal-service use for people with Alzheimer's disease', American Journal Of Alzheimer's Disease And Other Dementias, 19(5): 299-308.

Hassink, W. H. J. \& van den Berg, B. (2011) 'Time-bound opportunity costs of informal care: consequences for access to professional care, caregiver support, and labour supply estimates', Social Science \& Medicine (1982), 73(10): 1508-1516.

Hong, L. (2006) 'Involvement of informal and formal service providers: meeting the home care needs of older adults with severe functional impairments', Home Health Care Services Quarterly, 25(3-4): 167-183.

Hong, S. I. (2010) 'Understanding patterns of service utilization among informal caregivers of community older adults', The Gerontologist, 50(1): 87-99.

Jackson, D. McCrone, P. \& Turner-Stokes, L. (2013) 'Costs of caring for adults with long-term neurological conditions', Journal Of Rehabilitation Medicine, 45(7): 653-661.

Jacobs, J. C. Lilly, M. B. Ng, C. \& Coyte, P. C. (2013) 'The fiscal impact of informal caregiving to home care recipients in Canada: how the intensity of care influences costs and benefits to government', Social Science \& Medicine (1982), 81102-109.

Jakobsen, M. Poulsen, P. B. Reiche, T. Nissen, N. P. \& Gundgaard, J. (2011) 'Costs of informal care for people suffering from dementia: evidence from a danish survey', Dementia and Geriatric Cognitive Diseases, 1(1): 418-28.

Jansson, W. Nordberg, G. \& Grafstrom, M. (2001) 'Patterns of elderly spousal caregiving in dementia care: an observational study', Journal of advanced nursing, 34(6): 804-812.

Jimenez-Martin, S. \& Prieto, C. V. (2012) 'The Trade-Off between Formal and Informal Care in Spain', European Journal of Health Economics, 13(4): 461-490.

Jönsson, L. Eriksdotter Jönhagen, M. Kilander, L. Soininen, H. Hallikainen, M. Waldemar, G. Nygaard, H. Andreasen, N. Winblad, B. \& Wimo, A. (2006) 'Determinants of costs of care for patients with Alzheimer's disease', International Journal Of Geriatric Psychiatry, 21(5): 449-459.

Joseph, A. E. \& Hallman, B. C. (1998) 'Over the hill and far away: Distance as a barrier to the provision of assistance to elderly relatives', Social Science \& Medicine (1982), 46(6): 631-639.

Katz, S. Ford, A. B. Moskowitz, R. W. Jackson, B. A. \& Jaffe, M. W. (1963) 'Studies of Illness in the Aged The Index of ADL: A Standardized Measure of biological and Psychosocial Function', Journal of the American Medical Association, 185(12): 914-919.

Lapierre, T. A. \& Keating, N. (2013) 'Characteristics and contributions of non-kin carers of older people: a closer look at friends and neighbours', Ageing and Society, 33(8): 1442-1468.

Larson, J. S. (1991) The Measurement of Health: Concepts and Indicators, Westport: Greenwood press.

Latif, E. (2006) 'Labour Supply Effects of Informal Caregiving in Canada', Canadian Public Policy, 32(4): 413-429.

Lavoie, J. P. (2000) Familles et soutien aux parents âgées dépendants, Montréal: L'Harmattan.

Law, M. \& Letts, L. (1989) 'A critical review of scales of activities of daily living', American Journal of Occupational Therapy, 43(8): 522-528. 
Lee, Y.-S. \& Waite, L. J. (2008) 'Husbands' and Wives' Time Spent on Housework: A Comparison of Measures', Journal of Marriage and Family, 67328-336.

Marcenaro-Gutierrez, O. D. de la Torre Diaz, R. \& Dominguez-Serrano, M. (2012) 'La provision de cuidados informales a las personas con discapacidad: Horas de cuidados y participacion en el mercado laboral. (Informal Care for the Disabled: Hours of Care and Labour Market Participation. With English summary.)', Revista de Estudios Regionales, (94): 107-137.

Marin, D. B. Dugue, M. Schmeidler, J. Santoro, J. Neugroschl, J. Zaklad, G. Brickman, A. Schnur, E. Hoblyn, J. \& Davis, K. L. (2000) 'The Caregiver Activity Survey (CAS): Longitudinal validation of an instrument that measures time spent caregiving for individuals with Alzheimer's disease', International Journal of Geriatric Psychiatry, 15680-686.

McDowell, I. (2006) Physical Disability and Handicap, Oxford: Oxford University Press.

Membrado, M. 'L'aide : déconstruction d'une catégorie dans le champ du vieillissement et de "I'aide informelle"', Université de Toulouse II Le Mirail - CIRUS-Cieu, perso.numericable.fr/ sitedurtf7/downloads/JE/jetxtmembrado.pdf

Membrado, M., 2005, Définitions de l'aide : des experts aux « profanes », in Clément, S. \& Lavoie, J. P. (ed.) Prendre soin d'un proche âgé Toulouse: ERES, 85-136

Midy, F. \& Grignon, M. (2002) 'La notion de coût dans les évaluations médico-économiques', Journal d'économie médicale, 20(2): 105-117.

Moore, M. J. Zhu, C. W. \& Clipp, E. C. (2001) 'Informal costs of dementia care: estimates from the National Longitudinal Caregiver Study', Journal of Gerontology: Social Sciences, 56(4): S219S228.

Neubauer, S. Holle, R. Menn, P. \& Grassel, E. (2009a) 'A valid instrument for measuring informal care time for people with dementia', International Journal of Geriatric Psychiatry, 24(3): 275-282.

Neubauer, S. Holle, R. Menn, P. \& Grässel, E. (2009c) 'A valid instrument for measuring informal care time for people with dementia', International Journal of Geriatric Psychiatry, 24(3): 275-282.

Neubauer, S. Holle, R. Menn, P. Grossfeld-Schmitz, M. \& Graesel, E. (2008) 'Measurement of informal care time in a study of patients with dementia', International Psychogeriatrics / IPA, 20(6): $1160-1176$.

Nordberg, G. von Strauss, E. Kåreholt, I. Johansson, L. \& Wimo, A. (2005) 'The amount of informal and formal care among non-demented and demented elderly persons-results from a Swedish population-based study', International Journal Of Geriatric Psychiatry, 20(9): 862-871.

Oliva-Moreno, J. Aranda-Reneo, I. Vilaplana-Prieto, C. González-Domínguez, A. \& Hidalgo-Vega, A. (2013) 'Economic valuation of informal care in cerebrovascular accident survivors in Spain', BMC Health Services Research, 13508-508.

Oliva, J. Vilaplana, C. \& Osuna, R. (2011) 'The social value of informal care provided to elderly dependent people in Spain', Gaceta Sanitaria / S.E.S.P.A.S, 25 Suppl 2108-114.

Paraponaris, A. \& Davin, B. (2015) 'Economics of the Iceberg: Informal Care Provided to French Elderly with Dementia', Value in Health, 18(4): 368-375.

Peña-Longobardo, L. M. \& Oliva-Moreno, J. (2014) 'Caregiver burden in Alzheimer's disease patients in Spain', Journal of Alzheimer's Disease, 43(4): 1293-1302.

Peña-Longobardo, L. M. \& Oliva-Moreno, J. (2015) 'Economic valuation and determinants of informal care to people with Alzheimer's disease', The European Journal of Health Economics, 16(5): 507-515. 
Perrig-Chiello, P. \& Hutchison, S. (2010) 'Family caregivers of elderly persons: A differential perspective on stressors, resources, and well-being', Journal of Gerontopsychology and Geriatric Psychiatry, 23(4): 195-206.

Rigaux, N. (2009) 'Informal care: burden or significant experience?', Psychologie et Neuropsychiatrie du Vieillissement, 7(1): 57-63.

Robert, P. Ferris, S. Gauthier, S. Ihl, R. Winblad, B. \& Tennigkeit, F. (2010) 'Review of Alzheimer's disease scales: is there a need for a new multi-domain scale for therapy evaluation in medical practice?', Alzheimer's research \& therapy, 2(4): 24.

Saillant, F. (1999) 'Chercher l'invisible : épistémologie et méthode de l'étude de soins', Recherches Qualitatives, 20125-158.

Saillant, F., 2000, Soigner, ultimement. De la nécessité de la providence des savoirs., in Simard, M. (ed.) Actes du 5ème symposium de recherche sur la famille Ste-Foy: Les Presses de l'Université du Québec, 25-38

Saillant, F. \& Dandurand, R. B. (2002) 'Gift, Reciprocity and Engagement in the Care of Close Relations', Cahiers de recherche sociologique, 3719-50.

Saillant, F. \& Gagnon, É. (2001) 'Responsabilité pour autrui et dépendance dans la modernité avancée. Le cas de l'aide aux proches', Lien social et Politiques, (46): 55.

Schneider, J. Hallam, A. Murray, J. Foley, B. Atkin, L. Banerjee, S. Islam, M. K. \& Mann, A. (2002) 'Formal and informal care for people with dementia: factors associated with service receipt', Aging \& Mental Health, 6(3): 255-265.

Shelkey, M. (2012) 'Katz Index of Independence in Activities of Daily Living (ADL)', Best Practices in Nursing Care to Older Adults, (2).

Shikiar, R. Shakespeare, A. Sagnier, P.-P. Wilkinson, D. McKeith, I. Dartigues, J.-F. \& Dubois, B. (2000) 'The Impact of Metrifonate Therapy on Caregivers of Patients with Alzheimer's Disease: Results from the MALT Clinical Trial', Journal of the American Geriatrics Society, 48(3): 268-274.

Soullier, N. (2011) 'L'implication de l'entourage et des professionnels auprès des personnes âgées à domicile', DREES Etudes et Résultats, 771.

Taylor, D. H., Jr. Kuchibhatla, M. \& Østbye, T. (2008) 'Trajectories of caregiving time provided by wives to their husbands with dementia', Alzheimer Disease And Associated Disorders, 22(2): 131136.

Tornquist, K. \& Sonn, U. (2014) 'Towards an ADL taxonomy for occupational therapists', Scandinavian Journal of Occupational Therapy, 2120-27.

van den Berg, B. Brouwer, W. B. F. \& Koopmanschap, M. A. (2004) 'Economic Valuation of Informal Care: An Overview of Methods and Applications', European Journal of Health Economics, 5(1): 36-45.

van den Berg, B. \& Ferrer, I. C. A. (2007) 'Monetary valuation of informal care: the well-being valuation method', Health Economics, 16(11): 1227-44.

van den Berg, B. \& Spauwen, P. (2006) 'Measurement of informal care: an empirical study into the valid measurement of time spent on informal caregiving', Health Economics, 15(5): 447-60.

Vittengl, J. White, C. McGovern, R. \& Morton, B. (2006) 'Comparative validity of seven scoring systems for the instrumental activities of daily living scale in rural elders', Aging \& mental health, 10(1): 40-47. 
Wang, H. Gao, T. Wimo, A. \& Yu, X. (2010) 'Caregiver Time and Cost of Home Care for Alzheimer's Disease: A Clinic-based Observational Study in Beijing, China', Ageing International, 35(2): 153165.

Weatherly, H. Drummond, M. Claxton, K. Cookson, R. Ferguson, B. Godfrey, C. Rice, N. Sculpher, M. \& Sowden, A. (2009) 'Methods for assessing the cost-effectiveness of public health interventions: key challenges and recommendations', Health Policy, 93(2-3): 85-92.

Wimo, A. Jonsson, L. \& Zbrozek, A. (2010) 'The Resource Utilization in Dementia (RUD) instrument is valid for assessing informal care time in community-living patients with dementia', The Journal of Nutrition Health \& Aging, 14(8): 685-690.

Wimo, A. \& Nordberg, G. (2007) 'Validity and reliability of assessments of time. Comparisons of direct observations and estimates of time by the use of the resource utilization in dementia (RUD)instrument', Archives Of Gerontology And Geriatrics, 44(1): 71-81.

Wimo, A. Nordberg, G. Jansson, W. \& Grafström, M. (2000) 'Assessment of informal services to demented people with the RUD instrument', International Journal Of Geriatric Psychiatry, 15(10): 969-971.

Wimo, A. Reed, C. C. Dodel, R. Belger, M. Jones, R. W. Happich, M. Argimon, J. M. Bruno, G. Novick, D. Vellas, B. \& Haro, J. M. (2013) 'The GERAS Study: a prospective observational study of costs and resource use in community dwellers with Alzheimer's disease in three European countries-study design and baseline findings', Journal Of Alzheimer's Disease: JAD, 36(2): 385-399.

Wolff, J. L. Dy, S. M. Frick, K. D. \& Kasper, J. D. (2007) 'End-of-life care: findings from a national survey of informal caregivers', Archives Of Internal Medicine, 167(1): 40-46. 